\title{
ISOLATION AND CHARACTERIZATION OF NUCLEASE MUTANTS IN NEUROSPORA CRASSA
}

\author{
T. ISHIKAWA, A. TOH-E, I. UNO AND K. HASUNUMA \\ Department of Botany, Faculty of Science, University of Tokyo, Hongo, Tokyo, Japan
}

Received January 2, 1969

\begin{abstract}
THE nuclease activity of Neurospora crassa is accounted for by a number of enzymes distinguishable physically and catalytically. Of these, two nucleases specific for both DNA and RNA have been well characterized (LINN and LEHMAN 1965, 1966). More recently, an extracellular ribonuclease, RNase $\mathrm{N}_{1}$, and two intracellular ribonucleases, $R N a s e N_{2}$ and $N_{3}$, have been described (Takai, Uchida and Egami 1966, 1967a, b). Possible functions of nucleases in cells may be the degradation of nucleic acids supplied from the surrounding environment and the turnover of nucleic acids within the cells. There arises, however, much difficulty and confusion when one attempts to understand these functions of nucleases. Furthermore, the genetics of these enzymes as well as the intracellular regulation of nucleic acid metabolism remain relatively unexplored. One approach to the elucidation of the functions of nucleases and the genetic mechanism involved in nucleic acid metabolism is to find mutants which lack one or more kinds of nuclease activity. Such mutants have been previously obtained in Escherichia coli (Gesteland 1966; Dürwald and HofFmann-BerLing 1968). The present paper describes a simple screening technique for the isolation of mutants of Neurospora with the ability to digest neither DNA nor RNA and demonstrates that two genes are responsible for the activity of a particular kind of nuclease. This nuclease appears to be a complex consisting of a nuclease and an inhibitor. Preliminary reports of this work have been published (IsHIKawA, Hasunuma and Toh-e 1967; Ishikawa, Toh-e, Hasunuma and Uno 1968).
\end{abstract}

\section{MATERIALS AND METHODS}

Materials: The wild-type strain 74A (ST. LAWRENCE) of Neurospora crassa was used to induce nuclease mutants and as a source of normal nucleases. Mutants 74A-Y234-M394 (ad-1) and 74A-T28-M4 (unknown locus), which require adenine or hypoxanthine, were also used to induce nuclease mutants. The following purine or pyrimidine-requiring mutants were used to test growth characteristics in various media: adenine-requiring mutants, ad-4 (F2), ad-8 (E6), ad-3A and ad-6; a guanine-requiring mutant, 74A-T51-M116 (IsHIKAwA, unpublished); pyrimidine-requiring mutants, pyr-1 (H263), pyr-2 (38502), pyr-3 (KS36) and pyr-4 (36601). The pyrimidine-requiring mutants were kindly supplied from the Fungal Genetics Stock Center, Hanover, New Hampshire.

Media: The phosphate-free medium was prepared by substituting $\mathrm{KCl}(1 \mathrm{~g} / \mathrm{l})$ in Fries minimal medium for $\mathrm{KH}_{2} \mathrm{PO}_{4}$. Appropriate amounts of RNA, DNA or mononucleotides were included in the sterile phosphate 6 ee medium as sole sources of phosphate. These media will be described in this paper as RNA medium, DNA medium or mononucleotide medium (e.g., 3 'AMP medium) depending on the supplement. 
Growth measurement: To test the growth rate in various media, conidial suspensions of various strains were inoculated into $20 \mathrm{ml}$ of liquid media in duplicate $100 \mathrm{ml}$ Erlenmeyer flasks. Mycelial mats were harvested after a designated time, dried and weighed.

Cell-free extracts: Mycelia were grown at $25^{\circ} \mathrm{C}$ for designated times in $1000 \mathrm{ml}$ Roux bottles containing $100 \mathrm{ml}$ of Fries minimal medium. Mycelial pads were harvested on a Buchner funnel, washed with deionized water, and frozen quickly. Frozen mycelia were first ground in $0.005 \mathrm{M}$

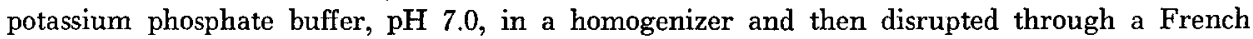
pressure cell at an average pressure of $400 \mathrm{~kg} / \mathrm{cm}^{2}$. Extracts were centrifuged at $15,000 \times \mathrm{g}$ for $30 \mathrm{~min}$ at $4^{\circ} \mathrm{C}$ and the supernatant solutions (crude extracts) were removed from the tubes with a syringe extending below the light lipid layer.

Fractionation of crude extracts: All the following operations were performed at $4{ }^{\circ} \mathrm{C}$. Cold ethanol $\left(-15^{\circ} \mathrm{C}\right)$ was added with constant stirring to the crude extract to a final concentration of $75 \%(\mathrm{v} / \mathrm{v})$. The precipitate formed was collected by centrifugation, dried and dissolved in $0.1 \mathrm{M}$ potassium phosphate buffer, $\mathrm{pH}$ 7.0. The enzyme preparation was fractionated by adding an appropriate amount of solid ammonium sulfate at $0^{\circ} \mathrm{C}$. The precipitate was collected by centrifugation, dissolved in $0.1 \mathrm{~m}$ potassium phosphate buffer, $\mathrm{pH} 7.0$, and used as a sample for chromatography.

Gel filtration was performed through Sephadex G-100. A gel column of suitable size was equilibrated and eluted with $0.005 \mathrm{~m}$ potassium phosphate buffer, $\mathrm{pH}$ 7.0. Blue Dextran 2000 and $\mathrm{NaCl}$ were included in all runs as indicators for the void volume and the end of elution, respectively. Elution positions of these indicators (arrows) added to the samples were determined by blue color for Blue Dextran (BD) and by precipitation with $\mathrm{AgNO}_{3}$ for $\mathrm{NaCl}$. A diethylaminoethyl (DEAE)-cellulose column $(1.5 \times 35 \mathrm{~cm})$ was equilibrated with $0.005 \mathrm{M}$ potassium phosphate buffer, $\mathrm{pH} 7.0$. Gradient elution was carried out with $\mathrm{NaCl}$ in a range $0-0.3 \mathrm{M}$.

Determination of RNase and DNase activities: The nuclease activities were measured by a modified method of TAKAHASHI (1961) using yeast RNA and salmon sperm DNA as substrates. The $1.0 \mathrm{ml}$ reaction mixture for assaying the ribonuclease (RNase) activity contained $1.5 \mathrm{mg}$ RNA, $0.1 \mathrm{~m}$ potassium phosphate buffer, $\mathrm{pH} 6.0,0.005 \mathrm{~m}$ ethylenediamine tetraacetic acid (EDTA) and $0.2 \mathrm{ml}$ of enzyme fraction. The reaction mixture for assaying the deoxyribonuclease (DNase) activity contained $0.25 \mathrm{mg}$ DNA instead of RNA and no EDTA. The reaction was started by the addition of substrate to the reaction mixture. Incubation was carried out at $37^{\circ} \mathrm{C}$ for 18 or $60 \mathrm{~min}$ to assay RNase or DNase, respectively. The reaction was stopped by adding $0.25 \mathrm{ml}$ of $25 \%$ perchloric acid containing $0.75 \%$ uranyl acetate. The mixture was allowed to stand in ice water at least for $10 \mathrm{~min}$. and was centrifuged at 3,000 rpm for $15 \mathrm{~min} .0 .2 \mathrm{ml}$ of the supernatant was diluted with $5 \mathrm{ml}$ of water and the optical density at $260 \mathrm{~m} \mu$ was measured. One unit of activity is defined as the amount of enzyme producing a change of absorbance of 1.0 under the conditions described above. The specific activity of RNase or DNase is expressed as units of activity per $\mathrm{mg}$ protetin.

Determination of proteolytic activity: Casein digestion was followed by incubating $1 \mathrm{ml}$ of crude extract with $1 \mathrm{ml}$ of a $1 \%$ solution of casein in $0.1 \mathrm{~m}$ phosphate buffer $(\mathrm{pH} 6.7)$ at $37^{\circ} \mathrm{C}$ for $20 \mathrm{~min}$. The reaction was started by the addition of casein to the reaction mixture and stopped by the addition of $3 \mathrm{ml}$ of $0.11 \mathrm{M}$ trichloroacetic acid containing $0.22 \mathrm{M}$ sodium acetate and $0.33 \mathrm{M}$ acetic acid. After centrifugation, the absorbance at $280 \mathrm{~m} \mu$ was determined against the blank to which the trichloroacetic acid solution described above was added at zero time. One unit of activity is defined as the amount of enzyme producing a change of absorbance of 1.0 under the conditions described above.

Assay for nuclease inhibitor activity: The activity of nuclease inhibitor was measured according to the method of Rотн (1958). An inhibitor preparation was added in the RNase-assay mixture containing nuclease $\mathrm{N}_{3}{ }^{\prime}$ described later before the addition of substrate. After leaving at $0^{\circ} \mathrm{C}$ for $60 \mathrm{~min}$, the RNase activity was measured as described above. The unit of inhibitor is defined as the unit of RNase activity that is $50 \%$ inhibited by the particular inhibitor preparation being tested. 
Protein measurement: Protein concentration was determined by the method described by Lowry, Rosebrough, FarR and Randall (1951).

Chemicals: RNA was kindly supplied by Prof. F. Egami. Salmon sperm DNA was a product of Calbiochem. (highly polymerized, A grade). Other special chemicals used were: casein (Merck); Sephadex G-100 and Blue Dextran (Pharmacia); DEAE-cellulose (Brown Co.).

\section{RESULTS}

Isolation of nuclease mutants: The Neurospora wild type shows considerable growth in RNA or DNA media. Some adenine requiring mutants can also utilize both RNA and DNA as a source of adenine. Nuclease mutants which can not grow in the RNA medium were obtained from wild-type 74A or adenine-requiring mutants by the filtration-concentration technique of Woodward, DE ZEEUW and SRB (1954) as revised by CASE (1963). Macroconidia, untreated or exposed to ultraviolet light (UV) or X rays, were utilized to obtain mutants. Conidia suspended in the RNA medium were incubated at $34^{\circ} \mathrm{C}$ in a low speed reciprocating shaker. Following filtration, platings were made on minimal agar (in case of an adenine-requiring mutant, adenine was added), and single colonies were isolated for testing. Nuclease mutants were identified by testing growth ability in liquid minimal medium supplemented with $100 \mu \mathrm{g} \mathrm{RNA}$ in place of $\mathrm{KH}_{2} \mathrm{PO}_{4}$. 168 nuclease mutants which do not utilize RNA have been thus isolated to date (Table 1).

Classification of nuclease mutants: Preliminary classification of nuclease mutants was made by means of the heterocaryon tests described by IsHIKawa (1962). Utilizing several arbitrarily chosen mutant strains as standards, all other nuclease mutants were tested for heterocaryon complementation with these strains by mixing conidial suspensions of the two mutants on the RNA agar medium. On the basis of these heterocaryon tests, two distinct groups of mutants were detected: group A (58 mutants) and group B (110 mutants) as described in Table 1. Combinations between group A mutants and group $B$ mutants were found to show a positive heterocaryon response on the RNA medium after two days at $25^{\circ} \mathrm{C}$.

Further evidence for two distinct groups of mutants has been obtained from genetic studies. Opposite mating types were obtained through backcrosses with 3.1 a wild type. Five independent crosses between mutants in groups $A$ and $B$ gave approximately $25 \%$ wild-type segregants, indicating that groups $\mathrm{A}$ and $\mathrm{B}$ are

TABLE 1

Origin of nuclease mutants

\begin{tabular}{ccccc}
\hline & \multicolumn{4}{c}{ Mutants derived from conidia exposed to: } \\
Group & UV & X rays & No treatment & Total \\
\hline A & 24 & 30 & 4 & 58 \\
B & 39 & 71 & 0 & 110 \\
Total & 63 & 101 & 4 & 168 \\
\hline
\end{tabular}


not linked. Crossing analyses have shown that group A mutants are located at one locus in linkage group I which is designated as nuclease-1 (nuc-1). Group B mutants are located at a second locus in linkage group II which is designated as nuclease-2 (nuc-2). In the preliminary report (Ishikawa, Hasunuma and Ton-E 1967) these two loci were designated as $R N a s e-1$ and $R N$ ase-2, respectively. In subsequent work, A1 (74A-T28-M1) and B1 (74.A-T28-M2) were usually used as the two representative mutant strains for groups $\mathrm{A}$ and $\mathrm{B}$, respectively. $\mathrm{A}$ double mutant of these two loci, A1 B1 was isolated after tetrad analysis of a cross between $\mathrm{A} 1$ and $\mathrm{B} 1$.

Growth characteristics of nuclease mutants: The wild-type 74A and nuclease mutants isolated were examined for their response to various concentrations of RNA, DNA and nucleotides as shown in Figure 1. The wild type utilizes these substances for growth on a minimal medium without phosphate. Nuclease mutants exhibit negative or very much reduced growth responses on RNA or DNA media. Group B mutants show considerable leaky growth in the RNA medium. Mutants of both groups could utilize adenosine 3'-monophosphate (3'-AMP) as a source of phosphate as shown in Figure 1. Other nucleotides, adenosine 5'-mono-
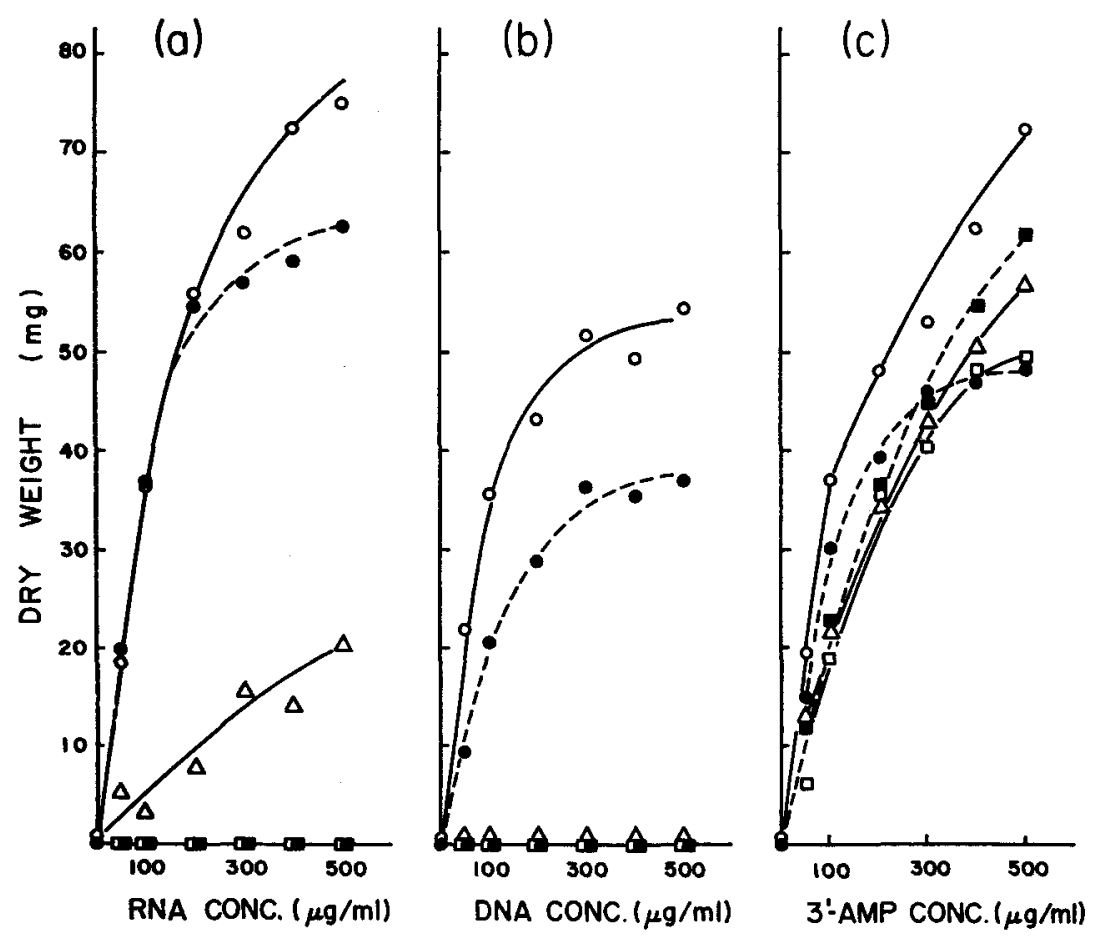

FIGURE 1.-Growth characteristics of the wild type and nuclease mutants in phosphate-free media supplemented with various amounts of RNA, DNA or 3'-AMP. Growth is expressed as mg dry weight of mycelia in $100 \mathrm{ml}$ Erlenmeyer flasks containing $20 \mathrm{ml}$ of media at $25^{\circ} \mathrm{C}$ for 72 hrs. (a) RNA media. (b) DNA media. (c) 3'-AMP media. Strains used: 74A (O); A1 ( $\square$ ); B1 $(\triangle)$; A1B1, double mutant $(\mathbf{G}) ; A 1+B 1$, heterocaryon $(\bullet)$. 
phosphate (5'-AMP), guanosine $3^{\prime}$-monophosphate, (3'-GMP), guanosine 5'monophosphate (5'-GMP), uridine $5^{\prime}$-monophosphate (5'-UMP) and cytidine $5^{\prime}$-monophosphate (5'-CMP), were equally utilized as sources of phosphate. However, the growth of nuclease mutants on nucleotide media was slightly less than that of the wild type. Heterocaryons formed between A1 and B1 utilized nucleic acids although the amount of growth in nucleic acid media was less than that of the wild type. Nuclease mutants show no significant difference from the wild type in either growth rate in minimal medium (Table 2) or in morphological characteristics.

Mutants requiring purines or pyrimidines were tested for their ability to utilize nucleic acids as a source of purine or pyrimidine which these mutants require (Table 2). Adenine-nonspecific mutants such as $a d-1, a d-3$ and $a d-6$ mutants which grow on either adenine or hypoxanthine utilized RNA or DNA as a source of adenine. Phosphate in the culture media repressed significantly the utilization of nucleic acids as indicated in Table 2. Double mutants between $a d-6$ and A1 or B1 failed to utilize nucleic acids as a source of adenine, indicating that A1 and B1 mutations are really related to the supply of purine from nucleic acids. Adenine-specific mutants such as $a d-4$ and $a d-8$ mutants which do not grow on hypoxanthine did not utilize nucleic acids as a source of adenine. A guaninerequiring mutant utilized nucleic acids slowly as a source of guanine. It is well known that the growth of adenine-specific mutants is stimulated by the presence of histidine (MaGaSANIK 1958; IshiKawa 1962). However, the growth response of adenine- and guanine-requiring mutants to nucleic acids was not affected by the addition of histidine. Pyrimidine-requiring mutants at the four known loci, pyr-1, pyr-2, pyr-3 and pyr-4, showed no significant growth on nucleic acids as a source of pyrimidine.

Nuclease activity in wild type and nuclease mutants: The wild type and some of the nuclease mutants were grown on minimal medium and the RNase and DNase activities of culture filtrates and crude mycelial extracts prepared from them were assayed (Table 3). No significant difference in the RNase activity was observed between culture filtrates of the wild type and of nuclease mutants, whereas no detectable DNase activity was found in culture filtrates of all strains tested. On the other hand a significant difference in the RNase and DNase activities of crude mycelial extracts was observed between the wild type and nuclease mutants.

Since crude mycelial extract of the wild type contains at least three species of RNase and of DNase (HASUNUMA and UNo, unpublished), the nuclease species responsible for the reduced nuclease activities found in crude extracts of nuclease mutants should be identified after fractionation. Therefore, crude extracts prepared from 7-day old mycelia of the wild type and nuclease mutants were subjected to filtration through Sephadex G-100. Two major peaks were found in the RNase assay in potassium phosphate buffer, $\mathrm{pH} 6.0$, in the presence of EDTA (Figure 2a). The second peak corresponds in chromatographic mobility and in pH optimum to RNase $\mathrm{N}_{3}$ described by TAKaI, Uchida and Egami (1967b) and designated here as nuclease $\mathrm{N}_{3}$. The same chromatogram was analyzed for DNase 


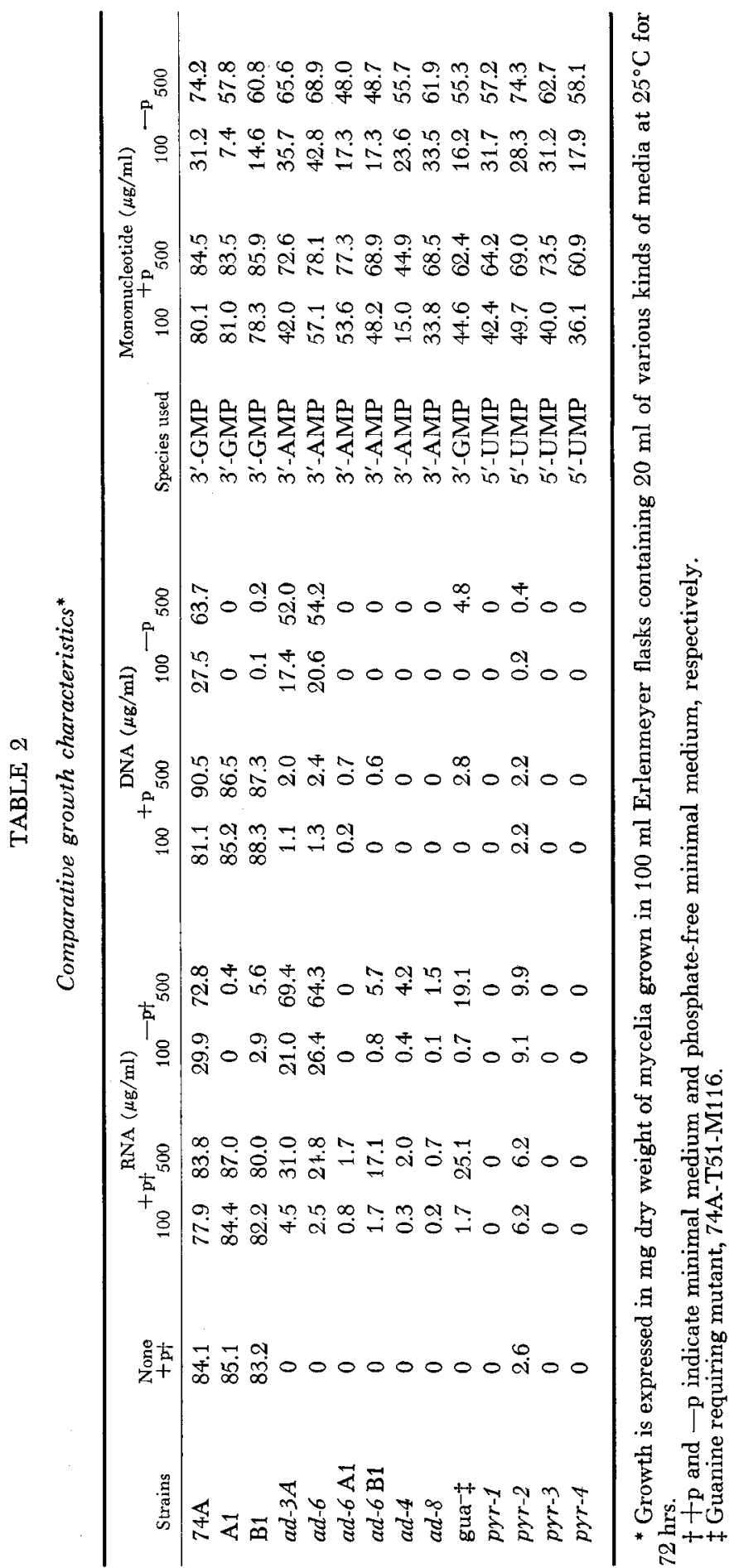


TABLE 3

Nuclease activity in culture filtrates and crude extracts of wild type and mutant cultures of various ages

\begin{tabular}{|c|c|c|c|c|c|c|c|c|}
\hline \multirow[b]{2}{*}{$\begin{array}{c}\text { Culture age } \\
\text { (days) }\end{array}$} & \multicolumn{4}{|c|}{ RNase activity } & \multicolumn{4}{|c|}{ DNase activity } \\
\hline & $74 \mathrm{~A}$ & $\mathrm{~A} 1$ & B1 & A1 B1 & $74 \mathrm{~A}$ & $\mathrm{~A} 1$ & B1 & $\mathrm{A} 1 \mathrm{~B} 1$ \\
\hline \multicolumn{9}{|c|}{ Culture filtrate* } \\
\hline 3 & 0.090 & 0.066 & 0.073 & 0.091 & 0.003 & 0.000 & 0.002 & 0.001 \\
\hline 5 & 0.356 & 0.331 & 0.344 & 0.471 & 0.005 & 0.000 & 0.000 & 0.001 \\
\hline 7 & 0.837 & 0.883 & 0.887 & 0.904 & 0.005 & 0.001 & 0.000 & 0.001 \\
\hline \multicolumn{9}{|c|}{ Crude extract $f$} \\
\hline 3 & 0.031 & 0.013 & 0.017 & 0.011 & 0.083 & 0.015 & 0.026 & 0.016 \\
\hline 5 & 0.078 & 0.028 & 0.044 & 0.028 & 0.087 & 0.055 & 0.044 & 0.052 \\
\hline 7 & 0.076 & 0.028 & 0.040 & 0.036 & 0.096 & 0.041 & 0.045 & 0.044 \\
\hline
\end{tabular}

* Units per ml culture filtrate.

+ Specific activity (units per mg protein).

activity. Two major peaks were found under the present assay conditions and the second one appeared to be identical in mobility with peak $N_{3}$ in the RNase assay (Figure 2a). Crude extracts of the two nuclease mutants, A1 and B1, were fractionated likewise through Sephadex G-100 (Figure 2b,c). In analyses for both RNase and DNase activities, the activity of peak $\mathrm{N}_{3}$ was significantly lower in both mutants than in wild type.

The nuclease peak $\mathrm{N}_{3}$ was partially purified by the following procedure. The crude extract prepared from 7-day old wild-type mycelia was subjected to ammonium sulfate fractionation. The nuclease activity precipitated between 40 and $60 \%$ saturation of ammonium sulfate $(231 \mathrm{~g} / 1$ and $369 \mathrm{~g} / \mathrm{l})$ at $0^{\circ} \mathrm{C}$ proved to be mostly peak $\mathrm{N}_{3}$ in succeeding Sephadex G-100 filtration (Figure 3a). Peak $\mathrm{N}_{3}$ thus obtained was further chromatographed on a DEAE-cellulose column (Figure $3 \mathrm{~b}$ ). Peak $\mathrm{N}_{3}$ always behaved as a single peak on chromatography, showing coinciding RNase and DNase activities. These results may indicate that peak $\mathrm{N}_{3}$ exhibits specificity toward both RNA and DNA.

Nuclease-inhibitor complex: The latency of the nuclease activity was first suggested by the fact that the RNase activity of a mycelial extract increased considerably after incubation at $37^{\circ} \mathrm{C}$. To analyze the activation process, the crude extract from 7-day old mycelia was prepared in potassium phosphate buffer (0.4 $\mathrm{M}, \mathrm{pH} 6.0)$ containing $\mathrm{MgCl}_{2}(0.001 \mathrm{M})$ and incubated at $37^{\circ} \mathrm{C}$ for several hours. $100 \mu \mathrm{g}$ per $\mathrm{ml}$ of streptomycin and penicillin were added in the incubation mixture to prevent bacterial contamination. The RNase activity was assayed without $\mathrm{MgCl}_{2}$ at $\mathrm{pH}$ 6.0. The maximum activation has been attained after 3 hours' incubation under the same conditions (Figure 4). A similar time and amount of maximum activation was observed for both mutants (A1, B1, A1B1) and wild type.

Crude extract obtained from wild-type mycelia was incubated as described above for $3 \mathrm{hrs}$, fractionated with ammonium sulfate, and subjected to filtration through Sephadex G-100. A new peak (fraction number 60-80) which is desig- 


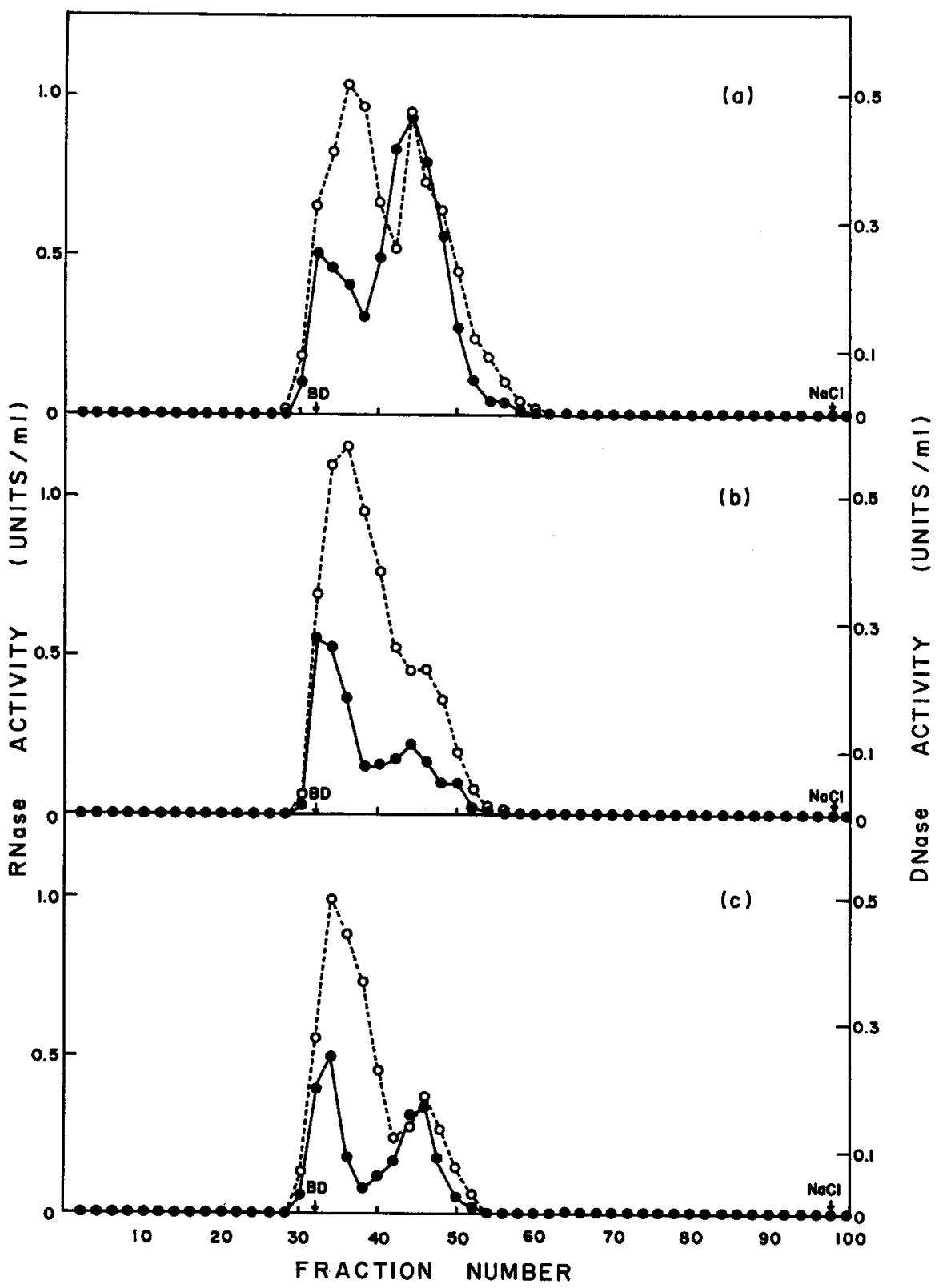

FIgure 2.-Filtration of crude extracts through Sephadex G-100. Crude extract obtained from 7-day old mycelia was precipitated with ethanol and subsequently with $100 \%$ ammonium sulfate. The enzyme preparation thus prepared was put onto a gel column $(1.5 \times 106 \mathrm{~cm})$ and eluted into $2 \mathrm{ml}$ fractions with $0.005 \mathrm{~m}$ potassium phosphate buffer $(\mathrm{pH} \mathrm{7.0)}$. Each fraction was assayed for the RNase and DNase activities. Elution positions of Blue Dextran (BD) and $\mathrm{NaCl}$ are indicated by arrows. (a) 74A. (b) A1. (c) B1. RNase activity (O); DNase activity (•). 


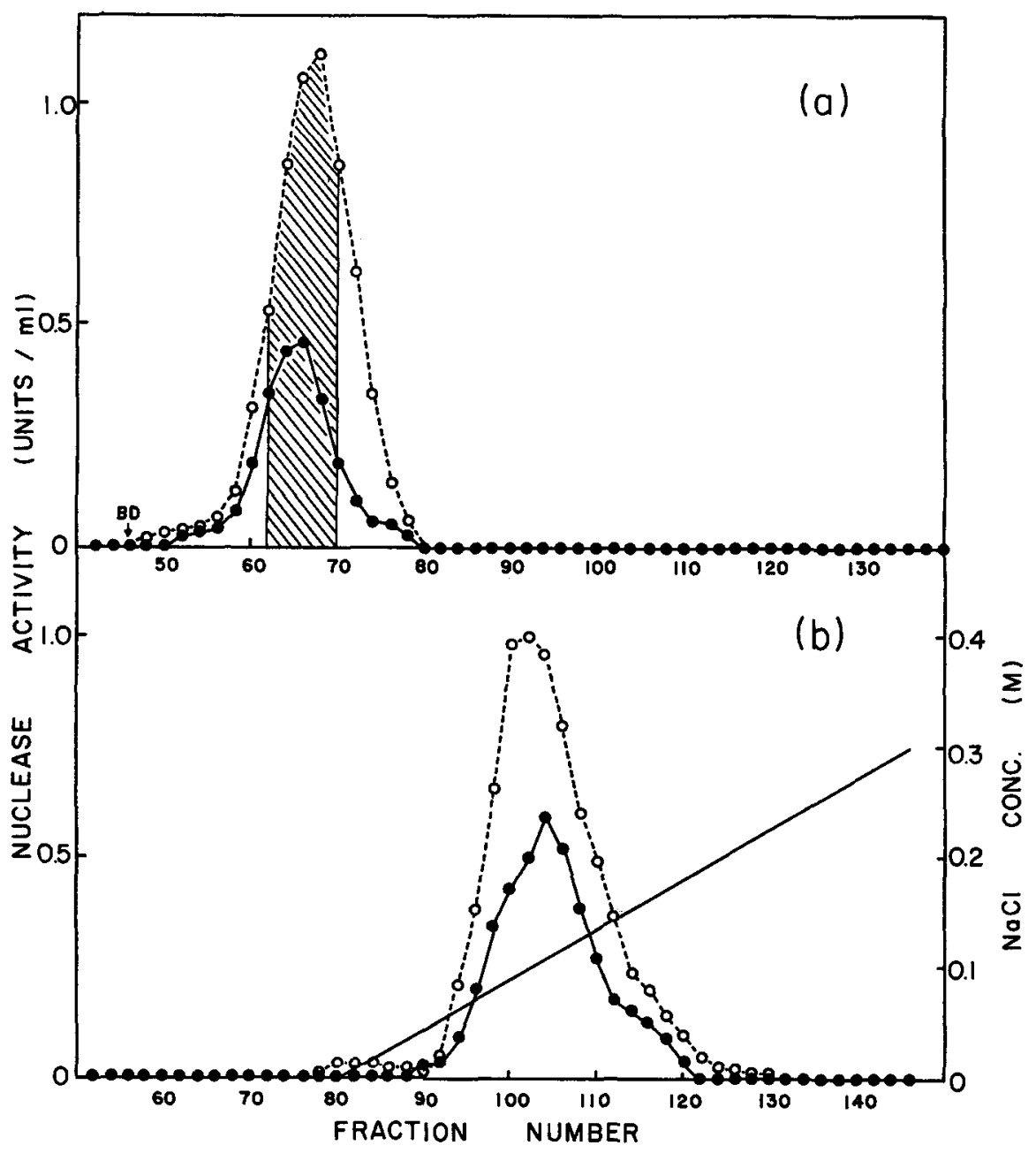

Figure 3.-DEAE-cellulose chromatography of peak $\mathrm{N}_{3}$ of the wild type obtained from Sephadex G-100 filtration. Crude extract obtained from 7-day old mycelia was precipitated with ethanol. The enzyme preparation subsequently precipitated between 40 and $60 \%$ ammonium sulfate saturation was filtered through a Sephadex G-100 column $(3 \times 75 \mathrm{~cm}) \cdot \mathrm{N}_{3}$ fraction shown by hatched region in the gel filtration was collected and chromatographed on a DEAE-cellulose column. Fractions $(4.0 \mathrm{ml})$ were eluted with a linear gradient of $\mathrm{NaCl}$ from 0 to $0.3 \mathrm{M}$. (a) Sephadex G-100 filtration. (b) DEAE-cellulose chromatograph. RNase activity (O); DNase activity ( $\bullet$; gradient of $\mathrm{NaCl}$ concentration (-).

nated here as nuclease $\mathrm{N}_{3}^{\prime}$ (designated previously as nuclease $\mathrm{N}_{5}$ by IsHikAwA et al. 1968) was observed after 3 hours' incubation at $37^{\circ} \mathrm{C}$ (Figure 5). The ratios of the DNase activity to the RNase activity at peak $N_{3}$ and $N_{3}{ }^{\prime}$ appeared to be different from preparation to preparation. The shift in these ratios from $N_{3}$ to $N_{3}^{\prime}$ observed after 3 hours' incubation at $37^{\circ} \mathrm{C}$ was not reproducible. The DNase activity found in fractions $30-40$ was increased but the RNase activity found in 


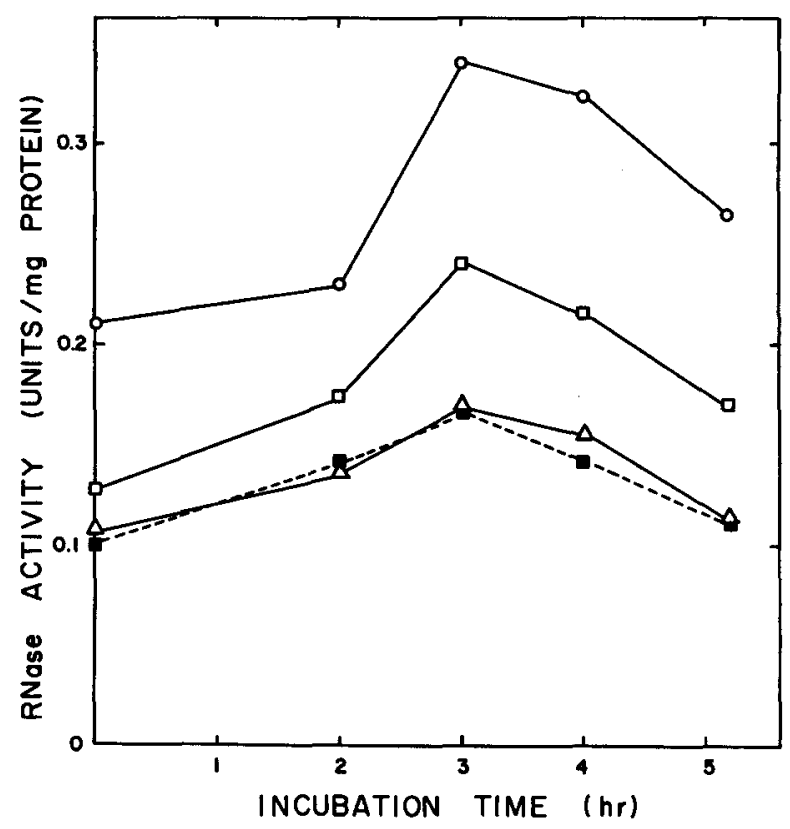

Frgure 4.--Effect of preincubation at $37^{\circ} \mathrm{C}$ on the RNase activity of crude extracts prepared from 7-day old wild-type and mutant mycelia. Preincubation was made in $0.4 \mathrm{M}$ potassium phosphate buffer, $\mathrm{pH} 6.0$ containing $0.001 \mathrm{M} \mathrm{MgCl}_{2} .100 \mu \mathrm{g}$ per $\mathrm{ml}$ of streptomycin and penicillin were added in the preincubation mixture to prevent bacterial contamination. See Figure 1 for symbols.

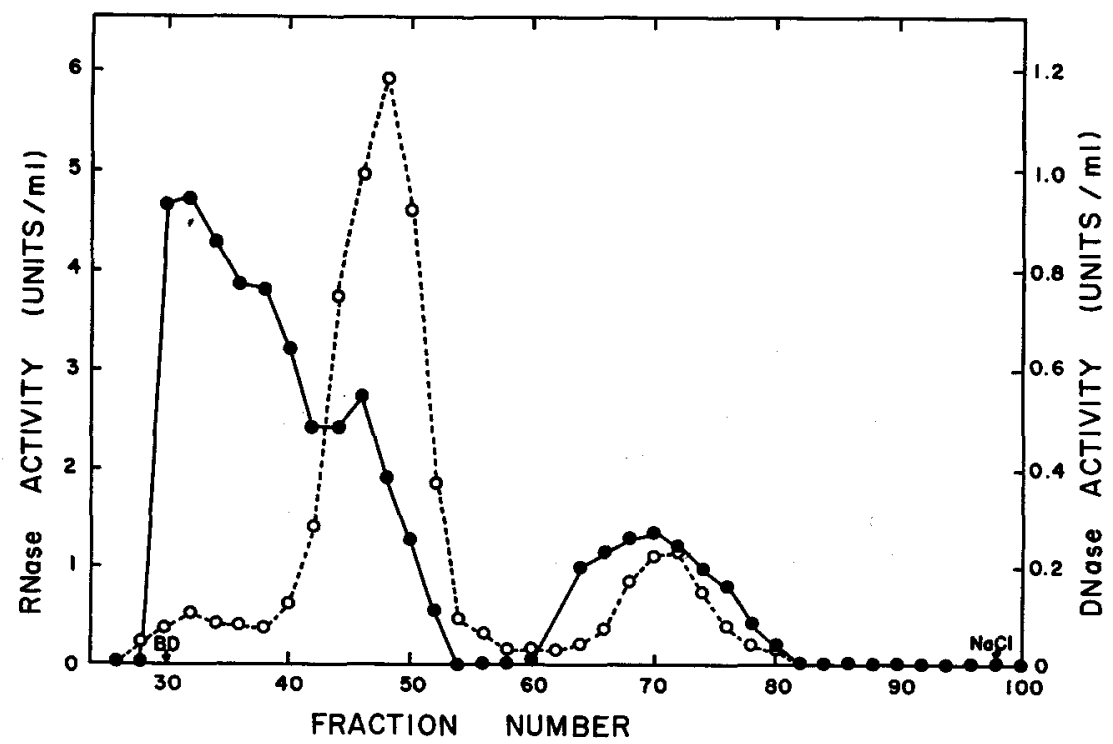

Figure 5.-Filtration of nucleases through Sephadex G-100 column $(1.5 \times 106 \mathrm{~cm})$ after incubating crude extract of wild-type mycelia at $37^{\circ} \mathrm{C}$ for $3 \mathrm{hrs}$ and precipitated with $60 \%$ ammonium sulfate. RNase activity (O); DNase activity $(\bullet)$. 
the same fractions was significantly reduced after incubation and subsequent ammonium sulfate fractionation. To confirm that peak $\mathrm{N}_{3}{ }^{\prime}$ had been derived from peak $\mathrm{N}_{3}$ during the incubation, the $\mathrm{N}_{3}$ fraction in the first gel filtration was collected, incubated at $37^{\circ} \mathrm{C}$ for another hour with $0.13 \mathrm{M}$ potassium phosphate buffer, $\mathrm{pH} 6.0$, containing $0.0003 \mathrm{M} \mathrm{MgCl}_{2}$, and rechromatographed through a Sephadex G-100 column. On the chromatogram thus obtained, only peak $\mathrm{N}_{3}{ }^{\prime}$ was observed instead of peak $N_{3}$ (Figure 6). This led to the conclusion that peak $\mathrm{N}_{3}{ }^{\prime}$ was actually derived from peak $\mathrm{N}_{3}$. The mobility ratio of $\mathrm{N}_{3}{ }^{\prime}$ to $\mathrm{N}_{3}$ indicates a reduction of molecular weight of $c a .60 \%$.

Since proteolytic activity was observed in mycelial extracts of Neurospora, a possible participation of proteolytic enzymes in the activation of nuclease $\mathrm{N}_{3}$ was considered. Ten $\mu \mathrm{g}$ per $\mathrm{ml}$ of subtilopeptidase $\mathrm{A}$ was enough to activate nucleases in the crude extract in $1 \mathrm{hr}$ incubation at $37^{\circ} \mathrm{C}$ as shown in Figure 7. A rapid inactivation of nucleases was observed, however, at higher concentrations of subtilopeptidase A. The proteolytic activity of crude extracts obtained from the wild type and nuclease mutants, A1 and B1, was assayed, and no essential differences were found among these strains as indicated in Table 4.

To analyze the process of production of nuclease $\mathrm{N}_{3}{ }^{\prime}$ from $\mathrm{N}_{3}$, the following chemical reagents have been tested for their ability to produce peak $\mathrm{N}_{3}{ }^{\prime}$; monoiodoacetate, $p$-chloromercuribenzoate $(p-\mathrm{CMB})$, sodium dodecyl sulfate and $\beta$-mercaptoethanol. $\mathrm{N}_{3}$ fraction was obtained from wild-type mycelia and treated

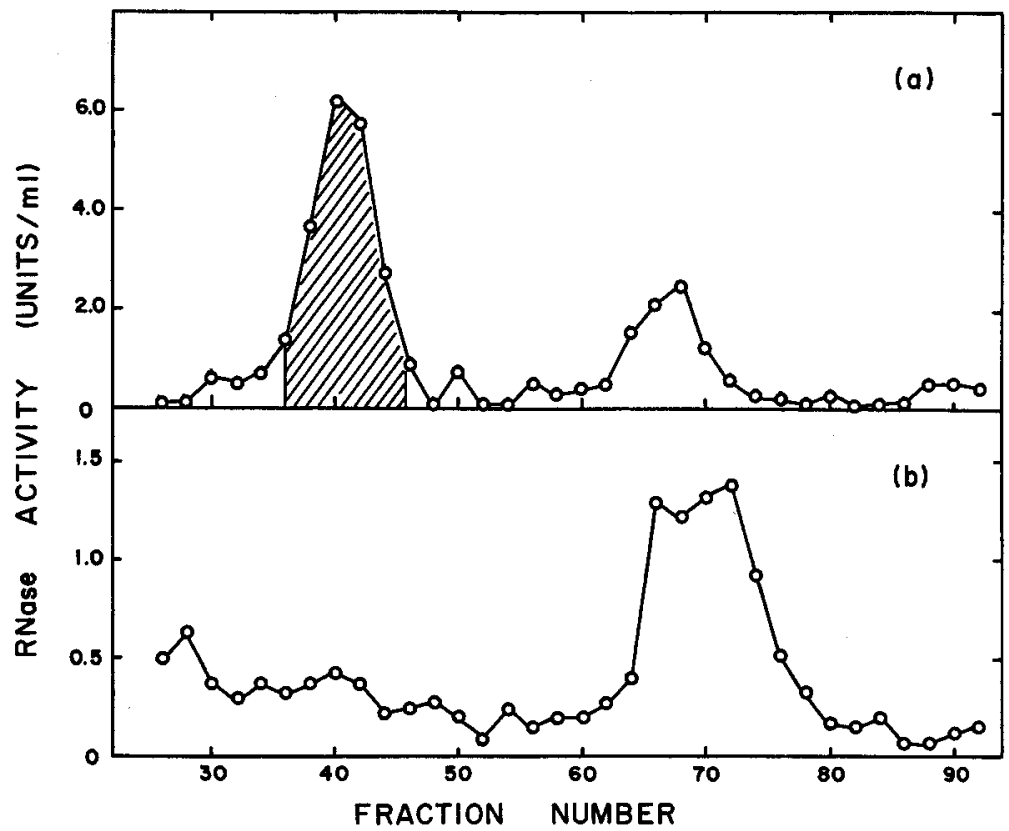

Frgure 6.-Production of peak $\mathrm{N}_{3}^{\prime}$ from peak $\mathrm{N}_{3} \cdot \mathrm{N}_{3}$ fraction obtained from the first Sephadex G-100 filtration $(1.5 \times 106 \mathrm{~cm}$ column $)$ as shown by hatched region was incubated at $37^{\circ} \mathrm{C}$ for $1 \mathrm{hr}$ and then applied on another column. The RNase activity was measured. (a) The first chromatograph. (b) The second chromatograph (after treatment). 


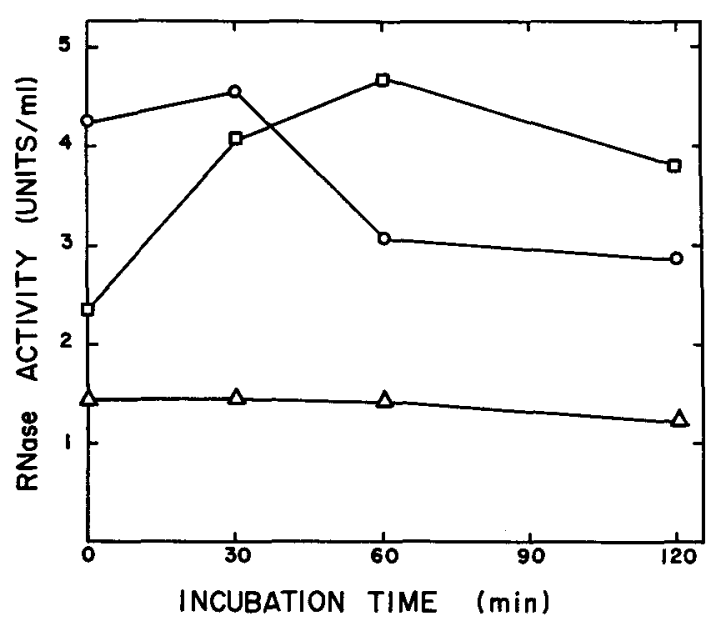

FIGURE 7.-Treatment of crude extract with subtilopeptidase A. Crude extract from 74A mycelia was incubated at $37^{\circ} \mathrm{C}$ in $0.4 \mathrm{M}$ potassium phosphate buffer, $\mathrm{pH} 6.0$ containing $0.001 \mathrm{M}$ $\mathrm{MgCl}_{2}$. Aliquots of crude extract thus incubated were removed at the designated time and assayed for the RNase activity. Concentrations of subtilopeptidase A: $0(\triangle) ; 10 \mu \mathrm{g} / \mathrm{ml} ;(\square) ; 100 \mu \mathrm{g} / \mathrm{ml}$ (O).

with these reagents for $10 \mathrm{~min}$ at $37^{\circ} \mathrm{C} .5 \mathrm{ml}$ of $\mathrm{N}_{3}$ fraction thus treated ( 25 units of RNase activity) were filtered through a Sephadex G-100 column $(2 \times 38 \mathrm{~cm})$, and the RNase activity was measured for fractions obtained after the gel filtration. As shown in Figure $8, p$-CMB $(0.001 \mathrm{M})$ and sodium dodecyl sulfate $(2 \%)$ were effective in producing peak $\mathrm{N}_{3}{ }^{\prime}$, whereas $\beta$-mercaptoethanol $(0.001 \mathrm{M})$ had no apparent effect on the $\mathrm{N}_{3}$ complex. The treatment with monoiodoacetate $(0.01 \mathrm{M})$ resulted in the production of peak $\mathrm{N}_{3}{ }^{\prime}$ with simultaneous disappearance of peak $\mathrm{N}_{3}$.

In a crude mycelial extract some part of nuclease $\mathrm{N}_{3}$ appears to exist in an active state, while another part remains in an inactive state. The concentration of inactive nuclease $\mathrm{N}_{3}$ involved in a mycelial extract was compared among the wild type and nuclease mutants. $\mathbf{N}_{3}$ fractions were prepared from 14-day-old mycelia and incubated at $37^{\circ} \mathrm{C}$ for $2 \mathrm{hrs}$ to activate nuclease $\mathrm{N}_{3} . \mathrm{N}_{3}$ fractions containing the same amount of the RNase activity ( 27 units) were further treated with monoiodoacetate $(0.01 \mathrm{M})$ at $37^{\circ} \mathrm{C}$ for $40 \mathrm{~min}$, and fractionated through a

TABLE 4

Proteolytic activity in crude extracts of wild type and mutant mycelia of various ages*

\begin{tabular}{ccccc}
\hline Culture age (days) & $74 \mathrm{~A}$ & A1 & B1 & A1 B1 \\
\hline 3 & 0.308 & 0.253 & 0.304 & 0.292 \\
5 & 0.320 & 0.272 & 0.270 & 0.280 \\
7 & 0.248 & 0.282 & 0.283 & 0.299 \\
\hline
\end{tabular}

* Specific activity (units per mg protein). 


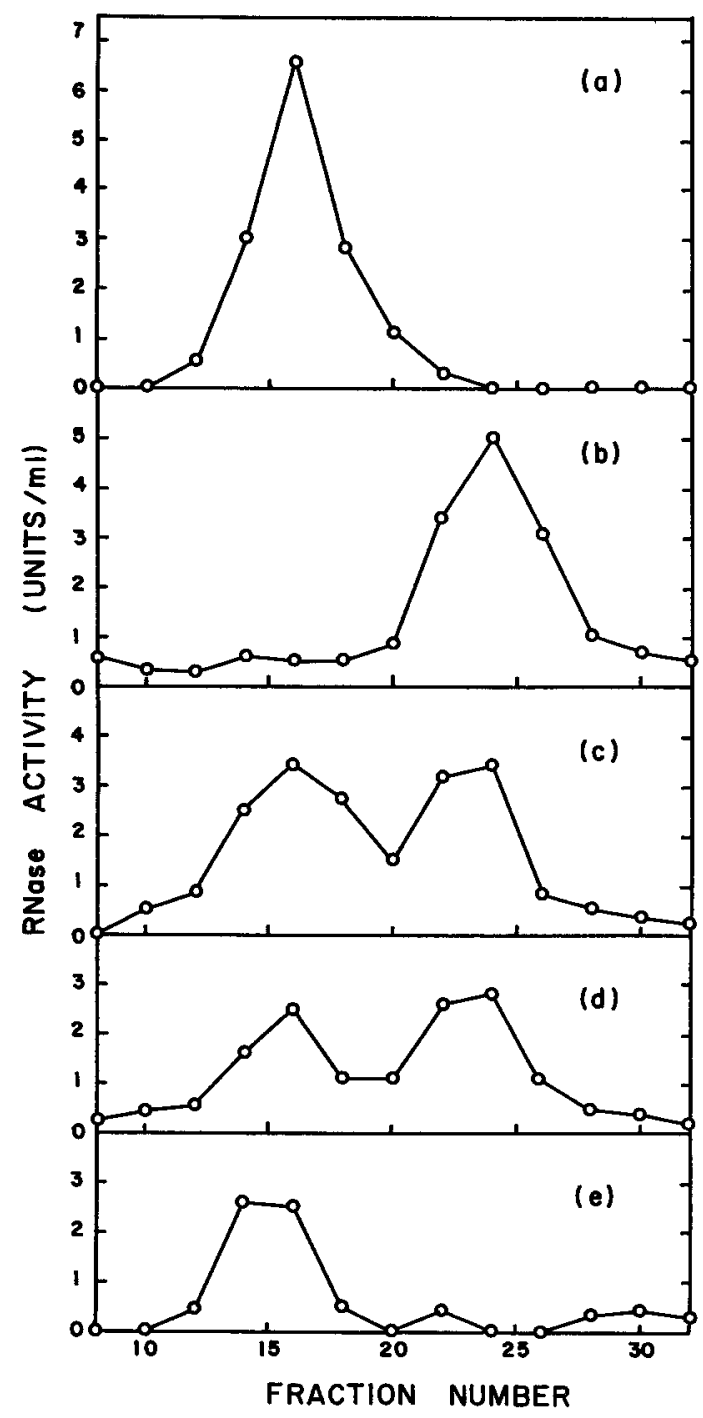

Figure 8.-Gel filtration of nuclease $\mathrm{N}_{3}$ complex treated with various reagents through Sephadex G-100. Nuclease $\mathrm{N}_{3}$ was obtained from 7-day old wild-type mycelia after Sephadex G-100 filtration, and treated with monoiodoacetate $(0.01 \mathrm{M})$, p-CMB $(0.001 \mathrm{M})$, sodium dodecyl sulfate $(2 \%)$ and $\beta$-mercaptoethanol $(0.001 \mathrm{~m})$ at $37^{\circ} \mathrm{C}$ for $10 \mathrm{~min} .5 \mathrm{ml}$ of $\mathrm{N}_{3}$ fraction (25 units of RNase activity) thus treated were filtered through a Sephadex G-100 column $(2 \times 38 \mathrm{~cm})$. $4 \mathrm{ml}$ fractions were collected and assayed for the RNase activity. (a) No treatment. (b) Monoiodoacetate. (c) $p$-CMB. (d) Sodium dodecyl sulfate. (e) $\beta$-mercaptoethanol.

Sephadex G-100 column $(2 \times 38 \mathrm{~cm})$. As shown in Figure $9, \mathrm{~N}_{3}$ activities were reduced and peak $\mathrm{N}_{3}{ }^{\prime}$ was observed. The RNase activity of peak $\mathrm{N}_{3}{ }^{\prime}$ produced from the $\mathrm{N}_{3}$ fraction of the mutant strain $\mathrm{B} 1$ was three times as high as that produced from $\mathrm{N}_{3}$ fraction of $74 \mathrm{~A}$ or A1. The result indicates that group B mu- 


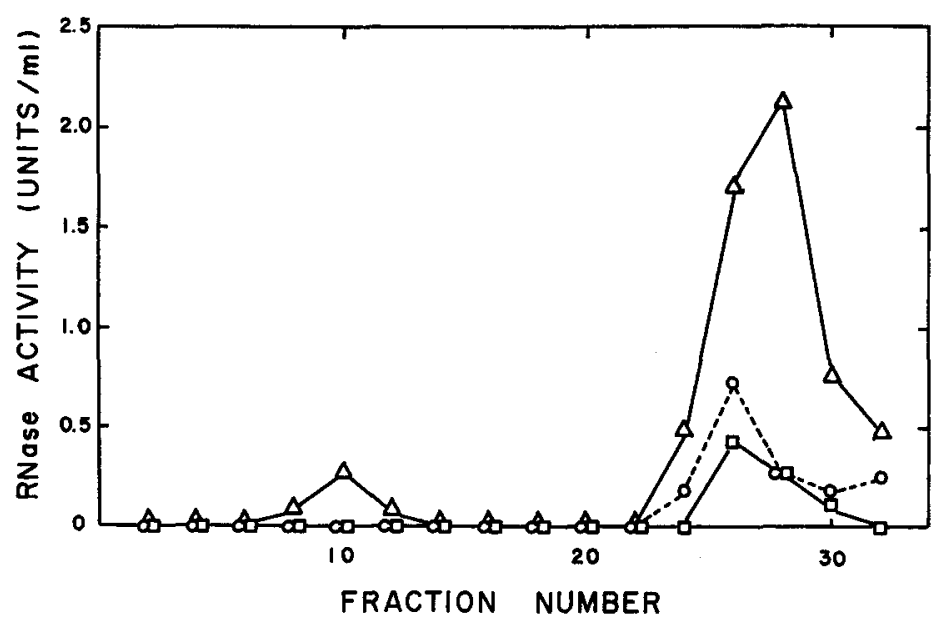

Figure 9.-Amount of peak $\mathrm{N}_{3}{ }^{\prime}$ appearing after the treatment of peak $\mathrm{N}_{3}$ with monoiodoacetate. Peak $\mathrm{N}_{3}$ fractions were prepared from 14-day old mycelia of the wild type and nuclease mutants after gel filtration and incubated at $37^{\circ} \mathrm{C}$ for $2 \mathrm{hr} .5 .4 \mathrm{ml}$ of $\mathrm{N}_{3}$ fraction (27 units of RNase activity) thus prepared were treated further with $0.01 \mathrm{~m}$ monoiodoacetate at $37^{\circ} \mathrm{C}$ for 40 min. The RNase activity was assayed for fractions obtained through a Sephadex G-100 column $(2 \times 38 \mathrm{~cm})$. See Figure 1 for symbols.

tants have an excess of latent nuclease $\mathrm{N}_{3}$ in vivo which is dissociated and activated by monoiodoacetate, and also suggests that the nuc-2 mutation results in the alteration of the binding properties or of the dissociation process of nuclease $\mathrm{N}_{3}{ }^{\prime}$ and a natural inhibitor.

Characteristics of the inhibitor: It was found that the crude mycelial extract inhibits the RNase activity of $\mathrm{N}_{3}$ ' fraction when added to the reaction mixture in the RNase assay. This may reflect the presence of free inhibitor molecules in crude extracts. The free inhibitor could be assayed against the $\mathrm{N}_{3}{ }^{\prime}$ fraction prepared from an extract of 14-day old wild-type 74. A mycelia by incubation at $37^{\circ} \mathrm{C}$ for $4 \mathrm{hr}$. The inhibitor activity of crude extracts from 5-day old and 10-day old mycelia of the wild type and nuclease mutants was assayed. As described in Table 5, 5-day old mycelia appear to contain a larger amount of inhibitor activity than 10-day old mycelia in all strains tested. Crude extracts from B1 and the double mutant, A1 B1, exhibited a tendency to have higher inhibitor activity than those from the wild type and A1. The result may indicate that B1 mycelia contain a more efficient inhibitor or a larger amount of inhibitor.

The inhibitor activity found in wild-type mycelial extract was stable at $37^{\circ} \mathrm{C}$ for at least $1 \mathrm{hr}$ in $0.50 \mathrm{~m}$ potassium phosphate buffer, $\mathrm{pH} 6.0$, containing 0.0005 $\mathrm{M} \mathrm{MgCl}_{2}$, but it was completely inactivated at $60^{\circ} \mathrm{C}$ within $15 \mathrm{~min}$. No significant difference has been observed in the heat stability among inhibitors obtained from the wild type and nuclease mutants.

\section{DISCUSSION}

A large number of nuclease mutants in Neurospora crassa has been isolated by a simple selection procedure for their inability to digest nucleic acids added 
TABLE 5

Inhibitor activity found in crude extracts of wild type and nuclease mutants

\begin{tabular}{|c|c|c|c|c|}
\hline Strain & $\begin{array}{c}\text { Culture age } \\
\text { (days) }\end{array}$ & $\begin{array}{c}\text { Amount } \\
\text { of protein } \\
\text { (mg/0.1ml extract) }\end{array}$ & $\begin{array}{c}\text { Inhibitor } \\
\text { activity } \\
\text { (units } / 0.1 \mathrm{ml} \text { extract) }\end{array}$ & $\begin{array}{c}\text { Specific } \\
\text { activity } \\
\text { (units } / \mathrm{mg} \text { protein) }\end{array}$ \\
\hline \multirow[t]{2}{*}{$74 \mathrm{~A}$} & 5 & 0.341 & 0.189 & 0.560 \\
\hline & 10 & 0.218 & 0.089 & 0.411 \\
\hline \multirow[t]{2}{*}{ A1 } & 5 & 0.302 & 0.149 & 0.495 \\
\hline & 10 & 0.200 & 0.064 & 0.322 \\
\hline \multirow[t]{2}{*}{ B1 } & 5 & 0.315 & 0.228 & 0.722 \\
\hline & 10 & 0.204 & 0.103 & 0.504 \\
\hline \multirow[t]{2}{*}{ A1 B1 } & 5 & 0.311 & 0.246 & 0.791 \\
\hline & 10 & 0.223 & 0.142 & 0.637 \\
\hline
\end{tabular}

* Unit of inhibitor activity is defined as the unit of nuclease $\mathrm{N}_{3}^{\prime}$ activity that is $50 \%$ inhibited by the crude extract being tested, when added in the RNase-assay procedure before the addition of substrate and left at $0^{\circ} \mathrm{C}$ for $60 \mathrm{~min}$.

to the culture medium. A single mutation resulted in a loss of ability to digest either RNA or DNA. Sephadex G-100 filtration experiments revealed that the mutation resulted in reduced nuclease activity of a particular nuclease fraction, $\mathrm{N}_{3}$ present in cell extracts. The $\mathrm{N}_{3}$ fraction has been previously reported by TAKal et al. (1967b) to be a kind of ribonuclease which digests RNA, producing guanylate and oligonucleotides with a terminal guanylate. In the present work, it was shown that exactly the same elution profiles of the $\mathrm{N}_{3}$ fraction on Sephadex G-100 filtration and subsequent DEAE-cellulose chromatography were obtained for both RNase and DNase activities. Furthermore, nuclease $\mathrm{N}_{3}{ }^{\prime}$ derived from the $\mathrm{N}_{3}$ fraction by certain treatments also exhibited specificity toward both RNA and DNA. This evidence indicates that peaks $\mathrm{N}_{3}$ and $\mathrm{N}_{3}{ }^{\prime}$ are two kinds of nuclease which have specificity toward both RNA and DNA. However, more work is required to explain why the ratios of RNase activity to DNase activity were different from preparation to preparation. RNase $N_{1}$ found in culture filtrate of the wild type (TAKAI et al. 1966) appears to have a similar molecular weight and the same specificity to produce guanylate as compared with nuclease $\mathrm{N}_{3}{ }^{\prime}$. However, no DNase activity was observed in culture filtrates of both wild type and nuclease mutants, and the activity of RNase $\mathrm{N}_{1}$ of the mutants was of the same level as that found in the wild type. Thus, it is concluded that RNase $\mathrm{N}_{1}$ and nuclease $\mathrm{N}_{3}{ }^{\prime}$ are different molecular species and that the nuclease mutants described have normal RNase $\mathrm{N}_{1}$.

The digestion products of nucleic acids by Neurospora cells in vivo may not include pyrimidine except as oligonucleotides, since pyrimidine-requiring mutants were unable to utilize nucleic acids. The fact that adenine-non-specific mutants were able to utilize nucleic acids but adenine-specific mutants were not may indicate that the digestion products of nucleic acids may not be adenylate. Since adenine-non-specific mutants are unable to grow on guanylate and a guanine-requiring mutant utilizes nucleic acids at significantly low rates, it is 
suggested that the digestion products of nucleic acids in vivo may not include a significant amount of guanylate. Therefore, it is postulated from these results that the digestion products of nucleic acids are immediately transformed to inosinate or its derivatives as a precursor of adenylate and guanylate.

Evidence has been presented that nuclease $\mathrm{N}_{3}$ goes to $\mathrm{N}_{3}{ }^{\prime}$ and that possibly $\mathrm{IN}_{3}{ }^{\prime}$ goes to $\mathrm{N}_{3}{ }^{\prime}$ and $\mathrm{I}$, where $\mathrm{I}$ is an inhibitor molecule. The mobility change of $\mathrm{N}_{3}$ to $\mathrm{N}_{3}{ }^{\prime}$ on the Sephadex G-100 chromatogram indicates either that $\mathrm{N}_{3}$ is a polymer enzyme or that $\mathrm{N}_{3}$ releases I which has $c a .60 \%$ of the molecular weight of $\mathrm{N}_{3}$. The fact that the crude mycelial extract inhibits the RNase activity of $\mathrm{N}_{3}{ }^{\prime}$ may indicate the existence of free inhibitor molecules in crude mycelial extracts. The existence of a complex of nuclease and its inhibitor is well known in other organisms (Roth 1956, 1958; Lindberg 1967; Smeaton and Elluotr 1967). Fraction $\mathrm{N}_{3}$ may be heterogeneous, containing both active and inactive forms of nuclease, or it may contain only one, partially active species. The nuclease activity found in the crude mycelial extract and identified as the $\mathrm{N}_{3}$ complex in the first gel filtration was further activated after certain treatments. Free nuclease $\mathrm{N}_{3}{ }^{\prime}$ molecules may not be produced in vivo, since no $\mathrm{N}_{3}{ }^{\prime}$ fraction was observed without particular treatments such as incubation of extract at $37^{\circ} \mathrm{C}$ or its treatment with particular chemical reagents. The treatment of $\mathrm{N}_{3}$ complex with monoiodoacetate, $p$-chloromercuribenzoate or sodium dodecyl sulfate led to the formation of nuclease $\mathrm{N}_{3}{ }^{\prime}$. $\beta$-mercaptoethanol showed no such effect on $\mathrm{N}_{3}$ complex. These results may suggest that cysteine residue(s) participate in transforming the complex from an inactive state to an active state and in binding between nuclease $\mathrm{N}_{3}{ }^{\prime}$ and the natural inhibitor molecule. The inhibitor (if it is a distinct species) may be a protein since proteolysis led to dissociation, but its exact nature has not yet been elucidated.

Two genes, nuclease-1 (nuc-1) and nuclease-2 (nuc-2), have been identified in genetic analyses of nuclease mutants isolated. The mutations in either gene resulted in a similar phenotype, except that mutants at the nuc-2 locus were more leaky in the RNA medium than those at the nuc-1 locus. Enzymatic analyses indicated that the activity of nuclease $\mathrm{N}_{3}$ was significantly reduced in both groups of mutants. nuc-1 mutants have decreased activity of nuclease $\mathrm{N}_{3}{ }^{\prime}$ as well as nuclease $\mathrm{N}_{3}$. nuc-2 mutants possess supernormal latent nuclease $\mathrm{N}_{3}$ activity as revealed by the treatment with monoiodoacetate (Figure 9). A possible participation of proteolytic enzymes is proposed in the process of activation of nuclease $\mathrm{N}_{3}$ in vivo. However, the existence of more latent nuclease activity in mutant strain B1 may not be due to the lower activity of proteolytic enzymes in the cell, since no difference has been observed in the activity of proteolytic enzymes of the mycelia among the wild type and nuclease mutants (Table 4). Although no direct evidence has been obtained in this study for an altered inhibitor in these mutants, it was shown that crude extracts obtained from nuc-2 mutants exhibited an elevated level of inhibition. From these data it is suggested that the mutation at the nuc-2 locus does not affect the nuclease molecule itself, but increases the binding affinity of the inhibitor for free nuclease, $\mathrm{N}_{3}{ }^{\prime}$, resulting in a more completely inhibited complex. 
Thus the evidence obtained here suggests that the nuc-1 gene controls directly the activity of nuclease $\mathrm{N}_{3}{ }^{\prime}$ and that the nuc-2 gene affects the nuclease activity by controlling the activity of an inhibitor in some way. An alternative possibility may be that one of two genes controls a factor which has an effect on the dissociation of nuclease $\mathrm{N}_{3}$ to $\mathrm{N}_{3}{ }^{\prime}$ and $\mathrm{I}$, or on the depolymerization of nuclease $\mathrm{N}_{3}$ to $\mathrm{N}_{3}{ }^{\prime}$. To obtain a final conclusion, characterization of nuclease $\mathrm{N}_{3}, \mathrm{~N}_{3}{ }^{\prime}$ and inhibitor should be performed and direct effects of mutation on these molecules should be studied. Isolation and characterization of temperature-sensitive nuclease mutants may help to elucidate the roles of these genes.

Nuclease mutants isolated to date have no obvious defects that make them morphologically different from the wild-type strain. The same result has been obtained for RNase and DNase mutants isolated in Escherichia coli (DürwaLn and Hoffmann-Berdivg 1968). However, Neurospora nuclease mutants show slightly reduced growth in mononucleotide media. This may be due to a secondary physiological alteration in phosphate metabolism and further work on this point is now underway. Furthermore, our preliminary data indicate that nuc-2 mutants are more sensitive to ultraviolet light irradiation than the wild type (UNo and IsHrKaWA 1969). It seems most likely that these mutant strains will be useful for studies on the physiological roles and regulation mechanisms of nucleases in Neurospora.

The authors wish to express their appreciation to Professor F. Egami and Dr. T. Uchina for helpful advice and a supply of RNA. Thanks are also due to Mrsses T. Oguchi and H. Akiyama for their excellent technical assistance.

This work was supported by U. S. Public Health Service grant GA-10505 from the National Institute of General Medical Sciences, and in part by a research grant from the Ministry of Education of Japan.

Contribution no. 391 from the Division of Genetics and Cytology, Department of Botany, Faculty of Science, University of Tokyo.

\section{SUMIMARY}

One hundred and sixty eight mutants which utilize neither RNA nor DNA as a sole source of phosphorus have been isolated in Neurospora crassa. A single mutation results in a loss of ability to digest either RNA or DNA. Two genes, nuclease-1 (nuc-1) and nuclease-2 (nuc-2), were found to be responsible for such nucleic acid digestion. These mutants showed a reduced activity of a nuclease fraction, $N_{3}$, which was found in the wild-type cell extract and digested both RNA and DNA. After treatment with reagents such as monoiodoacetate or after incubation at $37^{\circ} \mathrm{C}$, the $\mathrm{N}_{3}$ fraction was transformed into another nuclease fraction $\mathrm{N}_{3}{ }^{\prime}$. It was suggested that nuclease $\mathrm{N}_{3}$ is a complex consisting of nuclease $\mathrm{N}_{3}{ }^{\prime}$ and an inhibitor molecule. Comparative studies of mutants indicated that the nuc-1 locus may be responsible for nuclease $\mathrm{N}_{3}{ }^{\prime}$ and the nuc-2 locus for the inhibitor.

\section{LITERATURE CITED}

CASE, M. E., 1963 Procedure for filtration-concentration experiments. Neurospora Newsletter 3: $7-8$. 
Dürwald, H., and H. Hoffmann-Berling, 1968 Endonuclease I-deficient and ribonuclease Ideficient Escherichia coli mutants. J. Mol. Biol. 34: 331-346.

Gesteland, R. E., 1966 Isolation and characterization of ribonuclease I mutants of Escherichia coli. J. Mol. Biol. 16: 67-84.

Ishikawa, T., 1962 Genetic studies of ad-8 mutants in Neurospora crassa. II. Interallelic complementation at the $a d-8$ locus. Genetics $47: 1755-1770$.

Ishikawa, T., K. Hasunuma, and A. Toh-E, 1967 Biochemical and genetical studies on ribonucleases in Neurospora crassa. Proc. 7th Intern. Congr. Biochem. Abstr. 4: 667.

Ismikawa, T., A. Toh-E, K. Hasunuma, and I. Uno, 1968 The mutation and control mechanism of the nuclease activity in Neurospora crassa. Proc. 12th Intern. Congr. Genet. 1: 20.

LindBerg, U., 1967 Purification from calf spleen of two inhibitors of deoxyribonucleases I. Physical and chemical characterization of the inhibitor II. Biochemistry 6: 323-335.

Linn, S., and I. R. Lehman, 1965 An endonuclease from Neurospora crassa specific for polynucleotides lacking an ordered structure I. Purification and properties of the enzyme. J. Biol. Chem. 240: 1287-1293. — 1966 An endonuclease from mitochondria of Neurospora crassa. J. Biol. Chem. 241 : 2694-2699.

Lowry, O. H., N. J. Rosebrough, A. L. Farr, and R. J. Randall, 1951 Protein measurement with the Folin phenol reagent. J. Biol. Chem. 193: 265-275.

Magasanik, B., 1958 The metabolic regulation of purine interconversions and of histidine biosynthesis, pp. 485-490. In: The Chemical Basis of Development. The Johns Hopkins Press.

Roter, J. S., 1956 Ribonuclease V. Studies on the properties and distribution of ribonuclease inhibitor in the rat. Biochim. Biophys. Acta 21:34-43. - 1958 Ribonuclease VII. Partial purification and characterization of a ribonuclease inhibitor in rat liver supernatant fraction. J. Biol. Chem. 231 : 1085-1095.

Smeaton, J. R., and W. H. Elitotr, 1967 Isolation and properties of a specific bacterial ribonuclease inhibitor. Biochim. Biophys. Acta 145: 547-560.

TAKAXYASHI, K., 1961 The structure and function of ribonuclease $T_{1} I$. Chromatographic purification and properties of ribonuclease $T_{1}$. J. Biochem. (Tokyo) 49: 1-8.

TakaI, N., T. Uchida, and F. Egami, 1966 Purification and properties of ribonuclease $\mathrm{N}_{1}$, an extracellular ribonuclease of Neurospora crassa. Biochim. Biophys. Acta 128: 218-220. _ 1967a Ribonucleases, phosphodiesterases, and phosphomonoesterases of Neurospora crassa in various culture conditions. J. Japan. Biochem. Soc. 39: 285-290. — 1967b Ribonucleases of Neurospora crassa. J. Japan. Biochem. Soc. 39 : 473-481.

UNO, I., and T. IsHikawa, 1969 The radiation sensitivity of nuclease mutants in Neurospora crassa. Mutation Res. 8: 239-246.

Woodward, V. W., J. R. De ZeEUw, and A. M. SRB, 1954 The separation and isolation of particular biochemical mutants of Neurospora by differential germination of conidia, followed by filtration and selective plating. Proc. Natl Acad. Sci. U. S. 40: 192-200. 